\title{
Articaine plus morphine versus articaine alone for pain control during endodontic debridement in patients with irreversible pulpitis - a randomized controlled trial
}

\author{
Artykaina plus morfina versus sama artykaina w leczeniu bólu podczas zabiegu \\ endodontycznego $z$ powodu nieodwracalnego zapalenia miazgi - badanie randomizowane, \\ kontrolowane
}

\author{
Joanna Stowik ${ }^{1 * \bowtie}$, Tomasz Kaczmarzyk ${ }^{2 *}$, Jadwiga Stypułkowska², Maria Chomyszyn-Gajewska ${ }^{3}$, \\ Małgorzata Zaleska², Anna Bednarczyk², Marcin Wnuk ${ }^{4}$
}

${ }^{1}$ Uniwersytet Jagielloński, Collegium Medicum, Zakład Profilaktyki i Stomatologii Eksperymentalnej, ul. Montelupich 4, 31-155 Kraków

${ }^{2}$ Uniwersytet Jagielloński, Collegium Medicum, Katedra Chirurgii Ortopedycznej, ul. Montelupich 4, 31-155 Kraków

${ }^{3}$ Uniwersytet Jagielloński, Collegium Medicum, Zakład Periodontologii, ul. Montelupich 4, 31-155 Kraków

${ }^{4}$ Uniwersytet Jagielloński, Collegium Medicum, Katedra Neurologii, ul. Botaniczna 3, 31-507 Kraków

$\triangle$ jjslowik@gmail.com

\begin{abstract}
Introduction: Standard local anaesthetics do not guarantee complete absence of pain during endodontic debridement of the inflamed pulp.

We investigated whether the addition of $1 \mathrm{mg}$ of morphine to local articaine anaesthesia as compared to articaine alone could reduce pain sensations during endodontic debridement and within $48 \mathrm{~h}$ after the procedure.

Materials and methods: Thirty-two patients with pain attributed to irreversible pulpitis of the first upper molar participated in this randomized, double-blind trial. Patients were randomly assigned either to the study group (patients receiving periapical injection of modified local anaesthetic solution with morphine, $\mathrm{n}=9$ ) or to the control group (patients receiving standard anaesthetic solution without morphine, $\mathrm{n}=23$ ). The pain intensity was assessed using the visual analogue scale and verbal score before and directly after endodontic debridement, as well as at $1,2,6,12,24$ and $48 \mathrm{~h}$ after the procedure.
\end{abstract}

Results: Neither the visual analogue scale nor verbal score differed between both groups before or during the endodontic debridement, as well as during 48-hour follow-up. However, there was an insignificant tendency for greater pain relief in patients treated with articaine and morphine at $12 \mathrm{~h}$ after endodontic debridement $(p=0.08)$. The study was funded by a Jagiellonian University in Poland (JU) grant, and was registered with the JU Ethical Committee No. 2008/K/ZDS/000518.

Conclusions: The addition of morphine to local articaine anaesthesia does not influence pain intensity in patients undergoing endodontic debridement in contrast to the previously described pain-relief effect in patients after oral surgery. However, future studies are needed to evaluate the role of opioids in local anaesthesia in endodontic procedures.

Keywords: pulpitis; endodontic debridement; articaine; morphine; pain.

\section{ABSTRAKT}

Wstęp: Standardowe znieczulenie miejscowe nie gwarantuje całkowitego ustąpienia bólu podczas zabiegu endodontycznego usuwania miazgi w stanie nieodwracalnego zapalenia.

Celem pracy było sprawdzenie, czy miejscowe znieczulenie za pomocą morfiny w dawce $1 \mathrm{mg}$ dodanej do standardowego znieczulenia za pomocą artykainy w porównaniu z samą artykainą zmniejszy odczuwanie bólu w czasie 48 godz. po zabiegu endodontycznym.

Materiały i metody: W podwójnie ślepej próbie klinicznej uczestniczyły 32 osoby, które miały nieodwracalne zapalenie miazgi pierwszego zęba trzonowego szczęki. Uczestnicy badania byli zrandomizowani do dwóch grup: grupy badawczej, która otrzymywała artykainę i morfinę ( $\mathrm{n}=9$ ), oraz grupy kontrolnej, która otrzymywała tylko artykainę $(\mathrm{n}=23)$. Nasilenie bólu badano za pomocą numerycznej skali oceny bólu oraz skali wzrokowo-analogowej przed zabiegiem oraz 1, 2, 6, 12, 24 i 48 godz. po zabiegu.
Wyniki: Nie stwierdzono istotnych różnic nasilenia bólu między dwoma grupami w obu skalach oceny bólu we wszystkich kolejnych punktach oceny aż do 48 godz. po zabiegu. Stwierdzono jedynie nieistotne statystycznie mniejsze odczuwanie bólu po 12 godz. $u$ chorych leczonych morfiną i artykainą $(p=0,08)$. Badanie było finansowane z grantu Uniwersytetu Jagiellońskiego (UJ) i miało zgodę Komisji Bioetycznej UJ nr: 2008/K/ZDS/000518. Wnioski: Dodanie morfiny do artykainy w celu mniejszego odczuwania bólu podczas endodontycznego usuwania miazgi w stanie nieodwracalnego zapalenia nie ma wpływu na odczuwanie bólu, choć większą skuteczność tego znieczulenia obserwowano wcześniej podczas zabiegów chirurgicznych w jamie ustnej. Wskazane są dalsze badania oceniające skuteczność opioidów w miejscowym znieczuleniu podczas zabiegów endodontycznych. Słowa kluczowe: zapalenie miazgi; zabiegi endodontyczne; artykaina; morfina; ból. 


\section{INTRODUCTION}

Effective local anaesthesia is crucial for the optimal management of painful endodontic emergencies caused by the increased tissue pressure resulting from an inflamed pulp $[1,2]$. However, the administration of a standard local anaesthetic solution does not always provide satisfactory anaesthesia of the dental pulp [3]. Low pH values of inflamed tissue prevent the local anaesthetic molecules from dissociating into the unionized lipid-soluble forms, and preclude their subsequent migration through the phospholipid membrane of the neuronal cells to exert their analgesic effect $[1,4,5]$. Thus, the efficacy of local anaesthesia in the site of inflammation may be decreased or even lacking [5].

Opioid receptors can be found in inflamed peripheral human tissues, including dental pulp [6, 7]. They are located mainly within the unmyelinated C-fiber neurons [8] which are responsible for transmission of dull pain due to pulpal inflammation [9]. Such a process may trigger the intra-axonal transport of specific receptors for opioids to the nerve endings in inflamed tissue [7] and, consequently, local application of opioid may produce analgesia at the site of inflammation $[1,5,10]$. Systemic opioid therapy is often hampered by central side effects, which is why peripheral opioid analgesia has an undoubted clinical relevance [11]. It may be exemplified by the long-lasting analgesic efficacy of intraarticular injections of opioids $[12,13]$ or, better still, by the prolonged analgesic effect of $10 \mathrm{mg}$ morphine administered into the inflamed temporomandibular joint [14].

Clinical demonstration of the higher analgesic efficacy of opioid local anaesthesia than standard local anaesthesia would allow the adaptation of this technique into clinical practice and might influence the current approach to the management of pulpal inflammation. However, studies comparing the efficacy of opioid local anaesthesia and standard local anaesthesia for endodontic procedures of inflamed dental pulp have been scarce, and have brought equivocal results $[1,5,15,16,17]$.

Here, we report the results of a study designed to evaluate whether the addition of morphine sulfate to the standard local anaesthetic solution articaine could provide better pain control during and after endodontic debridement of the first upper molar affected by irreversible pulpitis.

\section{MATERIALS AND METHODS}

Participants were recruited among consecutive patients presenting to the Institute of Dentistry at the Jagiellonian University (JU) Medical College in Cracow (Poland) with acute toothache.

Inclusion criteria consisted of: (1) clinical diagnosis of acute symptomatic irreversible pulpitis of the first upper molar; (2) severe spontaneous pain associated with the tooth; (3) vital teeth with painful sensitivity to percussion as well as prolonged and afflicting response to thermal stimuli; and (4) physical status graded as class I or II according to the American Society of Anaesthesiology.

Exclusion criteria comprised of: (1) presence of an acute endodontic or periodontal abscess or any periodontal disease requiring antibiotic administration; (2) pregnancy or lactation; (3) mental disability; (4) known allergy to opioids and/ or local anaesthetics; (5) renal or biliary calculosis; (6) drug or alcohol abuse; (7) respiratory insufficiency; (8) glaucoma; and (9) any analgesic intake within the previous $6 \mathrm{~h}$.

The study protocol was approved by the Bioethics Committee of the JU. The study was funded by JU grant No. 2008/K/ ZDS/000518. Eligible patients were invited to participate and received full information about the goal and procedures. Each subject gave his/her informed written consent before inclusion, and did not receive any financial compensation for participation in the trial.

The study protocol followed a randomized, single-centre, double-blind and active-controlled clinical design. Patients, clinicians, outcome assessors and statisticians were not aware of the allocated treatment. For concealment of allocation, fifty sealed and sequentially numbered opaque envelopes were prepared, each of them containing the group assignment for one patient determined in advance by a random number table. Solutions used in the study were coded and syringes used for the anaesthesia were blinded and given only a patient code number. The codes were broken at the termination of the study. All endodontic procedures were carried out in a standardized manner by the same board endodontist. A flow chart of patient recruitment according to the CONSORT statement is shown in Figure 1.

Patients were randomized into 1 of the 2 parallel groups. Subjects in both groups received standard local anaesthesia that included $1.8 \mathrm{~mL}$ of Septanest $\AA$ ( $1 \mathrm{~mL}$ contains $40 \mathrm{mg}$ of articaine hydrochloride and $0.005 \mathrm{mg}$ of epinephrine hydrochloride). Patients in the study group additionally received $1 \mathrm{mg}$ of morphine sulfate in $1 \mathrm{~mL}$ of isotonic solution, while subjects in the control group received $1 \mathrm{~mL}$ of isotonic solution only. Thus, each patient received the same amount of anaesthetic solution $(2.8 \mathrm{~mL})$ of identical appearance in a submucous injection (periapical anaesthesia in the vestibular region). The teeth were considered anaesthetized when two consecutive negative responses to electric pulp testing were achieved.

The investigator who performed the root canal treatment was blinded to the assignment. An access cavity was prepared and the pulp was extirpated using a barbed broach. The working length was determined electronically using an apex locator (Root ZX, J. Morita, Kyoto, Japan) $1 \mathrm{~mm}$ shorter than the apex with a size of 15 or 20 K-file and confirmed by periapical radiographs. The apical part of each root canal was prepared to a size of $25 \mathrm{~K}$-file or larger instrument, according to the size of the canal, with the step-back technique in a circumferential manner. $5.25 \%$ sodium hypochlorite was used as the irrigant solution for each instrument, whereas cleaning and shaping were performed in the presence of ethylenediaminetetraacetic acid gel (File-Eze, Ultradent, South Jordan, UT, USA). Canals were then dried with paper points, and calcium hydroxide 


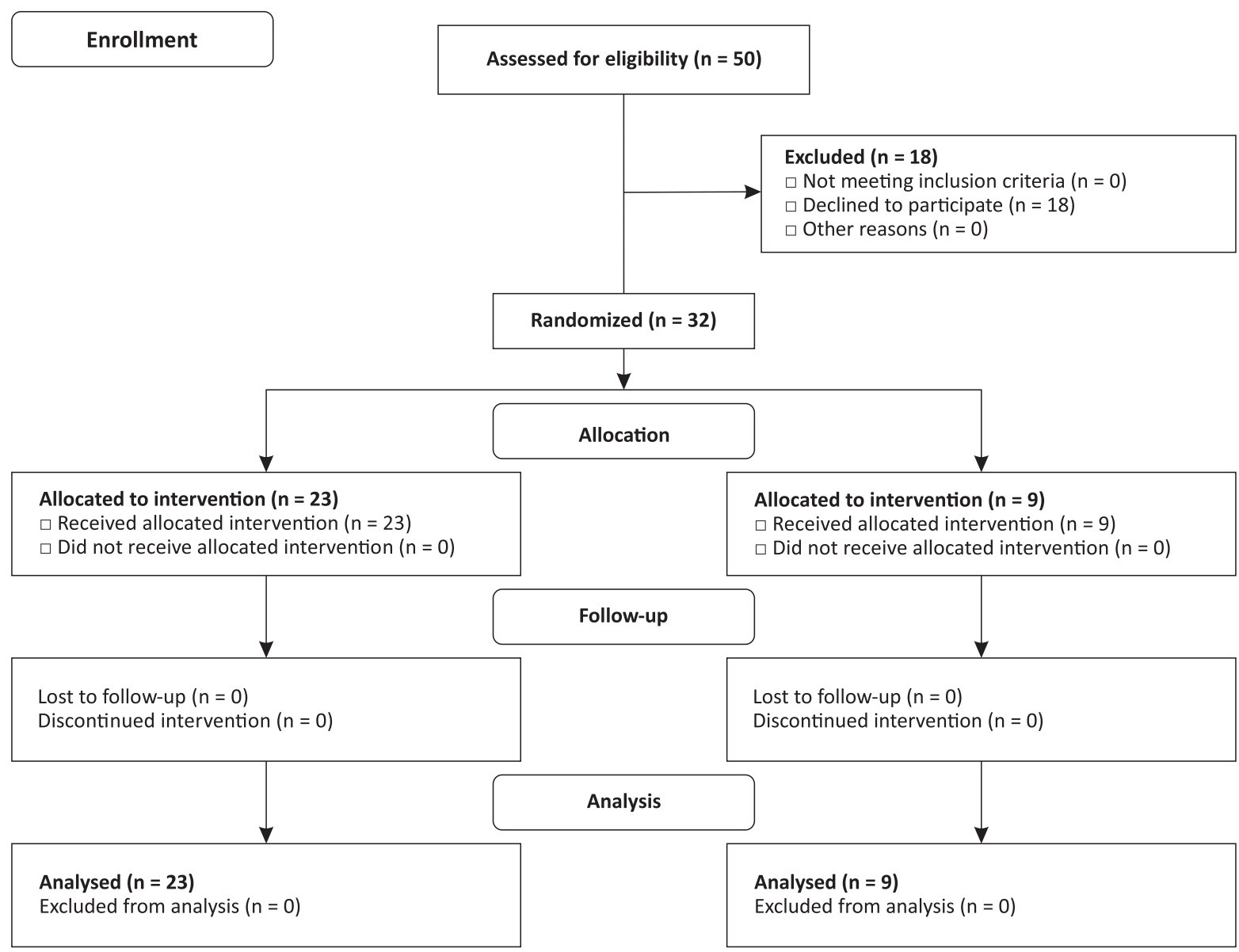

FIGURE 1. A flow chart of patient recruitment according to the CONSORT statement

paste (Hydrocal, Cerkamed, Poland) was inserted gradually with paper points. The access cavities were restored temporarily with a cotton pallet and Cavit (3M ESPE, St Paul, MN, USA). Obturation was performed at the second appointment. The time from anaesthesia administration to root canal procedure was standardized to 10 minutes for every patient.

Pain intensity was assessed using a $100 \mathrm{~mm}$ visual analogue scale ranging from absence of pain ( $0 \mathrm{~mm}$ ) to the worst pain imaginable (100 mm), and also verbal score, using 5 grades of pain intensity: 'none', 'slight', 'moderate', 'intense' and 'unbearable' pain. Before local anaesthesia, patients completed questionnaires based on the above scales detailing initial pain intensity. After local anaesthesia had been applied, patients were submitted to the standardized endodontic debridement. After completion of coronal dressing, patients completed another questionnaire concerning pain level during endodontic debridement. During the next 2 days patients were asked to complete further questionnaires that assessed the pain intensity at 1, 2, $6,12,24$ and $48 \mathrm{~h}$ after completion of endodontic debridement.

All statistical analyses were performed with Statistica v. 10 (StatSoft, Inc., Tulsa, OK, USA). The differences between the two groups regarding age and gender were analysed using Student t-test and $\chi^{2}$ test, respectively. The visual analogue scale and verbal score differences between the study and control groups before, during and within the 48-hour period after the procedure were analysed using the Mann-Whitney U-test. A p-value less than 0.05 was considered statistically significant.

\section{RESULTS AND DISCUSSION}

The participation in the trial was proposed to 50 consecutive patients who were considered eligible for endodontic treatment due to pain of the first upper molar at the JU Medical College, Institute of Dentistry in Cracow, between June 2006 and January 2007. All of them fulfilled the inclusion criteria and had no exclusion criteria.

However, only 32 subjects among them agreed to participate in the study and gave informed consent. For those participants their numbered opaque envelopes containing the group assignment were opened and the described procedure was introduced.

The number of envelope was identical with the number of the admission to the Department of the consecutive 50 patients that were considered for participation.

18 out of 50 cases refused to participate because of fear of being treated with an opioid.

The study group (i.e. patients treated with articaine plus morphine sulphate) comprised 9 subjects ( 5 women and 4 men), and the control group consisted of 23 patients ( 13 women and 


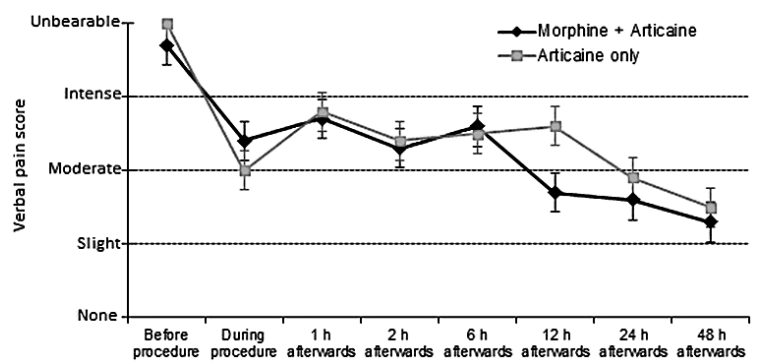

FIGURE 2. The verbal pain scores recorded at specific time intervals before, during and after endodontic debridement for both groups of patients (Mann-Whitney U-test)

10 men). There was no difference regarding sex ratio between groups $\left(\mathrm{p}=0.6 ; \chi^{2}\right.$ test). The average age of patients was $35.5 \pm 13.3$ years and did not differ significantly between the study group and control group (34.9 \pm 11.1 vs $35.7 \pm 11.4$ years, respectively; $\mathrm{p}=0.9$; Student t-test).

After randomization, all patients underwent endodontic debridement due to dental pulp inflammation according to the procedure described earlier. There were no protocol violations. Each patient received the treatment to which he/she was allocated.

The verbal pain scores did not show any significant differences between both groups, either before and during endodontic debridement ( $\mathrm{p}=0.4$ and $\mathrm{p}=0.6$, respectively; Mann-Whitney U-test), or during the 48-hour period of follow-up (Fig. 2).

Pain intensity, as assessed by the visual analogue pain scale, did not differ between studied groups, either before and during the endodontic debridement $(\mathrm{p}=0.9$ and $\mathrm{p}=0.7$, respectively; Mann-Whitney U-test), or during $48 \mathrm{~h}$ follow-up. A minor trend towards greater pain relief was noted in patients treated with articaine and morphine at $12 \mathrm{~h}$ after endodontic debridement ( $p=0.08$, Mann-Whitney U-test) - Table 1.

None of the patients in either group reported any side effects during endodontic debridement and during the $48 \mathrm{~h}$ follow-up.

\section{DISCUSSION}

Our study revealed that the addition of morphine sulfate to infiltrative articaine anaesthesia for endodontic debridement due to pulpitis was not associated with alleviation of pain intensity measured by either the visual analogue scale or verbal score. However, a minor trend towards greater pain relief at $12 \mathrm{~h}$ from the onset of endodontic debridement was observed in the group of patients treated additionally with morphine.

There are no studies evaluating the effectiveness of additional morphine administration to standard articaine anaesthesia in patients treated endodontically. Instead, previous studies showed that morphine may alleviate pain in patients undergoing endodontic treatment. Shantiaee et al. documented that periapical infiltration with $1 \mathrm{mg}$ of morphine considerably decreased postoperative endodontic pain at 4,8 and $24 \mathrm{~h}$ after the procedure when compared to placebo [18]. The periapical infiltration with $4 \mathrm{mg}$ of dexamethasone was even more effective than morphine in reducing pain intensity [18]. Similarly to our study, the investigators also used periapical infiltration as the method of morphine administration. The pain severity was also assessed using the visual analogue scale.

As mentioned before, previous research documented the presence of opioid receptors in inflamed dental pulp [6, 7]. However, only a few studies showed the effectiveness of local morphine administration in inflamed oral tissues in terms of the level of pain intensity $[5,16,18,19]$. Opioid receptors are transported intra-axonally to the site of inflammation within 1 or 2 days after the inflammatory process develops, with the maximum concentration of these receptors found on the $3^{\text {rd }}$ or $4^{\text {th }}$ day after the onset of inflammation $[7,8]$. Because of the usually insidious onset of the inflammatory process in endodontic diseases, it is possible that opioid receptors are present in the dental pulp in great concentrations, and thus morphine should have an evident analgesic effect very soon after its application. However, previous studies by Likar et al. $[16,19]$ showed the possible effect of morphine analgesia in oral surgery 10-12 h after drug administration. So far, there is no obvious explanation for this discrepancy. However, upregulation of opioid receptors in inflamed tissue seems to be important for the clinical effect of peripherally administered morphine $[20,21,22]$. The degree of inflammation could also play an important role in determining the extent of the clinical effect of peripherally administered opioids. For example, low degree of inflammation in osteoarthritis resulted in no pain

TABLE 1. Pain intensity assessed with the visual analogue scale $(\mathrm{mm})$ recorded at specific time points before, during and after endodontic debridement for both groups of patients (Mann-Whitney U-test)

\begin{tabular}{|c|c|c|c|}
\hline $\begin{array}{c}\text { Time since } \\
\text { endodontic debridement }\end{array}$ & $\begin{array}{l}\text { Control group } \\
\text { (patients treated with } \\
\text { articaine alone) } \\
n=23\end{array}$ & $\begin{array}{c}\text { Study group } \\
\text { (patients treatedwith articaine } \\
\text { plus morphine) } \\
n=9\end{array}$ & p \\
\hline Before debridement & $42 \pm 26$ & $44 \pm 31$ & 0.9 \\
\hline During debridement & $16 \pm 27$ & $25 \pm 38$ & 0.7 \\
\hline $1 \mathrm{~h}$ after the procedure & $18 \pm 26$ & $22 \pm 30$ & 0.8 \\
\hline $6 \mathrm{~h}$ after the procedure & $22 \pm 26$ & $11 \pm 17$ & 0.4 \\
\hline $12 \mathrm{~h}$ after the procedure & $23 \pm 24$ & $5 \pm 7$ & 0.08 \\
\hline $24 \mathrm{~h}$ after the procedure & $14 \pm 19$ & $5 \pm 9$ & 0.2 \\
\hline $48 \mathrm{~h}$ after the procedure & $9 \pm 13$ & $4 \pm 9$ & 0.5 \\
\hline
\end{tabular}


reduction after morphine injection into the temporomandibular joint [23].

Bigby et al. [15], in their single-blind trial, revealed that the addition of another opioid ( $36 \mathrm{mg}$ of meperidine) to a standard anaesthetic solution consisting of lidocaine and epinephrine did not result in lowering the pain intensity during endodontic debridement in patients with irreversible pulpitis of the mandibular posterior teeth [15]. However, these authors used a different method of opioid administration in comparison to our study, called inferior alveolar block, resulting in the perineural administration of the opioid [15]. In the case of irreversible pulpitis of the mandibular molar teeth, the site of inflammation is localized in the dental pulp, not in the pterygomandibular space, where meperidine has been administered. Since in non-inflamed tissues the perineurium barrier constitutes an impermeable guard that encases nerve fibres [7] and the failure of this barrier observed in inflamed tissue is vital for opioids to reach their specific receptors [24], the administration of meperidine into non-inflamed tissue failed to demonstrate any analgesic effect.

Finally, previous research by Kaczmarzyk and Stypulkowska [5] showed that local anaesthesia modified by the addition of morphine may be of benefit for the pain relief in patients undergoing surgical treatment due to inflamed oral and maxillofacial tissues. Such patients experienced a statistically significant reduction in operative and post-operative pain within $12 \mathrm{~h}$ after the procedure in comparison to patients receiving articaine only before surgery. There was also a considerable difference between both subgroups regarding the time of first additional analgesic intake and the total amount of analgesic dose [5]. However, the studied group was heterogeneous because it was comprised of patients with dental pulp necrosis as well as with complications due to difficult eruption of the third lower molar tooth. It is possible that infiltration of morphine in both mentioned subgroups of patients was different but the results were not presented separately. In our study, the group of patients was homogeneous due to more precise inclusion and exclusion criteria formed at the beginning of the study. The endodontic debridement was even performed in the same group of teeth - first upper molars.

Another explanation for the lack of demonstration of the effectiveness of morphine infiltration added to local anaesthesia is probably the low compliance of patients after endodontic debridement in contrast to patients undergoing dental surgical procedures. It is also possible that morphine does not penetrate to the apical foramen of the tooth. It is only known so far that the acid environment of the inflamed tissue found in many endodontic processes leads to fast dissociation of local anaesthetic to forms which cannot penetrate the phospholipid membrane of the neuronal cells [5] and, therefore, may result in poor effectiveness of local anaesthetics in the site of inflammation [25].

The small number of participants is a limitation, and therefore other studies should be performed on a larger population of patients.

What is more, since a large percentage of potential attendees refused to participate in the presented study (36\%), the applied process of randomization caused a heavy bias towards a much lower number of patients treated with articaine plus morphine sulphate as compared to articaine alone.

Nevertheless, the shown data evaluating adding the opioids to standard local anaesthetic solution should be valuable for further research on pain control during and after endodontic debridement.

\section{CONCLUSIONS}

In conclusion, the presented study showed that the addition of morphine to local anaesthesia with articaine does not influence the pain intensity in patients undergoing endodontic debridement in contrast to the previously described pain-relief effect in patients after oral surgery. However, due to the relatively small sample size, future studies are needed to evaluate the role of opioids in local anaesthesia in endodontic procedures.

\section{REFERENCES}

1. Elsharrawy EA, Elbaghdady YM. A double-blind comparison of a supplemental interligamentary injection of fentanyl and mepivacaine with 1:200,000 epinephrine for irreversible pulpitis. J Pain Symptom Manage 2007;33(2):203-7.

2. Srinivasan N, Kavitha M, Loganathan CS, Padmini G. Comparison of anesthetic efficacy of $4 \%$ articaine and $2 \%$ lidocaine for maxillary buccal infiltration in patients with irreversible pulpitis. Oral Surg Oral Med Oral Pathol Oral Radiol Endod 2009;107(1):133-6.

3. Meechan JG. Supplementary routes to local anaesthesia. Int Endod J 2002;35(11):885-96.

4. Hargreaves KM, Keiser K. Local anesthetic failure in endodontics: mechanism and management. Endod Topics 2002;1(1):26-39.

5. Kaczmarzyk T, Stypulkowska J. Assessment of the effectiveness of peripheral administration of morphine with local articaine anaesthesia for surgery in inflamed oral and maxillofacial tissues. Pain 2005;115(3):348-54.

6. Jaber L, Swaim WD, Dionne RA. Immunohistochemical localization of mu-opioid receptors in human dental pulp. J Endod 2003;29(2):108-10.

7. Stein C. The control of pain in peripheral tissue by opioids. N Engl J Med 2005;332(125):1685-90.

8. Bartho L, Stein C, Herz A. Involvement of capsaicin-sensitive neurons in hyperalgesia and enhanced opioid antinociception in inflammation. Naunyn Schwiedenbergs Arch Pharmakol 2009;342(60):666-70.

9. Narhi M. The neurophysiology of the teeth. Dent Clin North Am 1990;34(3):439-48.

10. Joris JL, Dubner R, Hargreaves KM. Opioid analgesia at peripheral site: a target for opioids released during stress and inflammation? Anesth Analg 1987;66(12):1277-81.

11. Oeltjenbruns J, Schäfer M. Peripheral opioid analgesia: clinical applications. Curr Pain Headache Rep 2005;9(1):36-44.

12. Raj N, Sehgal A, Hall JE, Sharma A, Murrin KR, Groves ND. Comparison of the analgesic efficacy and plasma concentrations of high-dose intraarticular and intramuscular morphine for knee arthroscopy. Eur J Anaesthesiol 2004;21(12):932-7.

13. Senthilkumaran S, Tate R, Read JR, Sutherland AG. Intra-articular morphine and bupivacaine for post-operative analgesia in anterior cruciate ligament reconstruction: a prospective randomised controlled trial. Knee Surg Sports Traumatol Arthrosc 2010;18(6):731-5.

14. Ziegler CM, Wiechnik J, Muhling J. Analgesic effects of intra-articular morphine in patients with temporomandibular joint disorders: a prospective, double-blind, placebo-controlled clinical trial. J Oral Maxillofac Surg 2010;68(3):622-7.

15. Bigby J, Reader A, Nusstein J, Beck M. Anesthetic efficacy of lidocaine/ meperidine for inferior alveolar nerve blocks in patients with irreversible pulpitis. J Endod 2007;33(1):7-10. 
16. Likar R, Koppert W, Blatnig H, Chiari F, Sittl R, Stein C, et al. Efficacy of peripheral morphine analgesia in inflamed, non-inflamed and perineural tissue of dental surgery patients. J Pain Symptom Manage 2001;21(4):330-7.

17. Uhle RA, Reader AI, Nist R, Weaver J, Beck M, Meyers WJ. Peripheral opioid analgesia in teeth with asymptomatic inflamed pulps. Anesth Prog 1997;44(3):90-5.

18. Shantiaee Y, Mahjour F, Dianat O. Efficacy comparison of periapical infiltrarion injection of dexamethsone, morphine and placebo for postoperative endodontic pain. Int Dent J 2012;62(2):74-8.

19. Likar R, Sittl R, Gragger K, Pipam W, Blatnig H, Breschan C, et al. Peripheral morphine analgesia in dental surgery. Pain 1998;76(1):145-50.

20. Schafer M, Imai Y, Uhl GR, Stein C. Inflammation enhances peripheral mu-opioid receptor-mediated analgesia, but not mu-opioid receptor transcription in dorsal root ganglia. Eur J Pharmacol 1995;279(2-3):165-9.
21. Shaqura MA, Zollner C, Mousa SA, Stein C, Schafer M. Characterization of mu opioid receptor binding and $\mathrm{G}$ protein coupling in rat hypothalamus, spinal cord, and primary afferent neurons during inflammatory pain. J Pharmacol Exp Ther 2004;308(2):712-8.

22. Zollner C, Shaqura MA, Bopaiah CP, Mousa S, Stein C, Schafer M. Painful inflammation-induced increase in mu-opioid receptor binding and G-protein coupling in primary afferent neurons. Mol Pharmacol 2003;64(2):202-10.

23. List T, Tegelberg A, Haraldson T, Isacsson G. Intra-articular morphine as analgesic in temporomandibular joint arthralgia/osteoarthritis. Pain 2001;94(3):275-82.

24. Antonijevic I, Mousa SA, Schäfer M, Stein C. Perineurial defect and peripheral opioid analgesia in inflammation. J Neurosci 1995;15(1Pt1):165-72.

25. Harris MH. The use of local anesthesia in the presence of inflammation. Oral Surg Oral Med Oral Pathol 1964;18:16-23. 